\title{
Physiology and philhellenism in the late nineteenth century: The self-fashioning of Emil du Bois-Reymond
}

\author{
Lea Beiermann* ${ }^{\star}$ and Elisabeth Wesseling \\ Maastricht University \\ ${ }^{\star}$ Corresponding author. Email: 1.beiermann@maastrichtuniversity.nl
}

\begin{abstract}
Argument
Nineteenth-century Prussia was deeply entrenched in philhellenism, which affected the ideological framework of its public institutions. At Berlin's Friedrich Wilhelm University, philhellenism provided the rationale for a persistent elevation of the humanities over the burgeoning experimental life sciences. Despite this outspoken hierarchy, professor of physiology Emil du Bois-Reymond eventually managed to increase the prestige of his discipline considerably. We argue that du Bois-Reymond's use of philhellenic repertoires in his expositions on physiology for the educated German public contributed to the rise of physiology as a renowned scientific discipline. Du Bois-Reymond's rhetorical strategies helped to disassociate experimental physiology from clinical medicine, legitimize experimental practices, and associate the emerging discipline with the more esteemed humanities and theoretical sciences. His appropriation of philhellenic rhetoric thus spurred the late nineteenth-century change in disciplinary hierarchies and helped to pave the way for the current hegemonic position of the life sciences.
\end{abstract}

Keywords: physiology; Du Bois-Reymond; discipline formation; interdisciplinarity; university history; life sciences; rhetoric; scientific self-fashioning

German physiologist Emil du Bois-Reymond has been described as "the most important forgotten intellectual of the nineteenth century” (Finkelstein 2013, xv). Born in 1818, he became a muchacclaimed physiologist, nationally and internationally. He was especially well known for his eloquent speeches on science and culture. At the height of his fame, his picture hung for sale in German shop windows together with photographs of other celebrities such as the members of the Prussian royal family (ibid.). Considering his position as professor of physiology and head of the physiological institute at Friedrich Wilhelm University in Berlin, du Bois-Reymond's unparalleled national fame seems rather unlikely. As Suzanne Marchand has shown, nineteenth-century Prussian culture and education were dominated by ubiquitous philhellenic ideals (Marchand 1996). Philhellenism was conducive to a strong predilection for the humanities in general, and philology in particular, which interfered with the establishment of the new-fangled experimental life sciences as prominent academic disciplines.

Philhellenism, having already influenced eighteenth-century artists through the art-historical writings of Johann Joachim Winckelmann, gained new momentum during the Greek War of Independence (1821-1832) and continued to influence European intellectual life throughout the nineteenth century (Marchand 1996; Williamson 2004). At its core was a fascination with ancient Greece, fed by the assumption that the ancient Greeks epitomized timeless beauty. Wilhelm von Humboldt, founding father of Berlin's university, was convinced that studying ancient Greek philosophy and philology was a prerequisite for all sound education. He therefore elevated Berlin's philosophical faculty high above the practice-oriented faculties of medicine, law, and theology

(C) The Author(s) 2020. Published by Cambridge University Press. This is an Open Access article, distributed under the terms of the Creative Commons Attribution licence (http://creativecommons.org/licenses/by/4.0/), which permits unrestricted re-use, distribution, and reproduction in any medium, provided the original work is properly cited. 
(Marchand 1996; Zimmerman 2001). As a result, as Emil du Bois-Reymond remarked, the term "scholar" (Gelehrter) was long used synonymously with "philologist" or "classicist" but not "natural scientist" (EBR 1891-1892). ${ }^{1}$ Overall, the philhellenic orientation of Berlin's university, which, as will be shown, pervaded research and teaching practices, was rather disadvantageous to the establishment of physiology as a renowned discipline. How, then, did Emil du Bois-Reymond rise to fame, establishing a cutting-edge research institute along the way, although Berlin's intellectual circles and its university were steeped in classical literary education?

In the course of the nineteenth century, research into the organic processes of living beings was thoroughly reshaped by novel research practices and instruments, culminating in the emergence of experimental physiology as an academic discipline. The microscopic discovery of cells in 1839 and the subsequent emergence of cell theory gradually replaced vitalist models of the body, which built on the assumption that an innate vital force distinguished living from non-living matter (Parnes 2003). Attempting to rid themselves of any vitalist remains that were increasingly perceived as pseudo-scientific, nineteenth-century physiologists strove to portray their discipline as no less scientific than the more acclaimed theoretical sciences (Finkelstein 2013). Whereas Rudolf Virchow, professor of pathological anatomy at Berlin's university, advocated a more traditional medicine centered on clinical applications, du Bois-Reymond claimed that gaining theoretical, physiological knowledge of healthy organisms through experiment should be a precondition of medical training (Jardine 1997). While vitalist physiology had been closely tied to medicine, the physicalist and experimentalist version propagated by du Bois-Reymond seemed to open a window of opportunity for closely associating physiology with the more prestigious philosophical faculty. ${ }^{2}$ Carving a niche for the emerging discipline of physiology among the theoretical sciences was likely to increase not only social appreciation but also research resources. Du Bois-Reymond could argue that physiology deserved to be granted as many benefits as the humanities and theoretical sciences, allowing for additional professorships and the establishment of research institutes.

Yet the deeply entrenched philhellenic discourse within academia and society at large remained rather ill-disposed to du Bois-Reymond's scientific endeavors. Progress continued to be associated with the arts rather than science or technology. As the Magazin für die Literatur des Auslandes asserted in 1873, responding to a speech made by du Bois-Reymond, the deeds of men like "Luther, Shakespeare, Goethe, must be regarded as the real hallmarks of progress" (Lehmann 1873). ${ }^{3}$ The physiological department long remained a rather neglected division of Berlin's university, whose equipment in the 1850s was still limited to "a rusty Voltaic pile and a moth-eaten foxtail" (EBR 1887, 362). However, in 1877, du Bois-Reymond supervised the opening of a brand new, fully equipped physiological institute, the most splendid scholarly building in town, an unmistakable sign of recognition and success (Dierig 2006). This does make one stop and wonder how du BoisReymond had managed to convince his superiors of the necessity of underwriting his discipline. ${ }^{4}$

So far, the successful establishment of experimental physiology as a prominent discipline at Berlin's university has been attributed to the scientific achievements of its practitioners, and to the urban infrastructure and international scientific reputation of Berlin (Tenorth 2012-2015; Dierig 2006). Du Bois-Reymond was part of a Berlin-centered network of international scientific luminaries, including Hermann von Helmholtz, who joined the university in 1871, Rudolf Virchow, and Robert Koch (Finkelstein 2013; Tenorth 2012-2015). Moreover, the renown of du Bois-Reymond's mentor, Johannes Müller, and his physiological research - although, in du

\footnotetext{
${ }^{1}$ To distinguish between references to the works of Emil du Bois-Reymond and a lecture transcript presumably made by his son Claude du Bois-Reymond, we refer to the former as EBR and to the latter as Claude du Bois-Reymond.

${ }^{2}$ The university's philosophical faculty accommodated not only the humanities but also the natural sciences, including the discipline of physics (Tenorth 2012-2015).

${ }^{3}$ Translation ours. We will quote from the English version of du Bois-Reymond's 1872 speech On the Limits of Our Knowledge of Nature, published in 1874. All other translations are ours.

${ }^{4} \mathrm{Du}$ Bois-Reymond was the driving force behind this development. Finkelstein writes, "The National-Zeitung named the institute du Bois-Reymond's 'most characteristic creation"” (Finkelstein 2013, 190).
} 
Bois-Reymond's eyes, tainted with natural philosophical speculation - provided the basis for the institutionalization of experimental physiology (Otis 2007). We claim that, in addition to his scientific achievements and far-reaching research networks, it was du Bois-Reymond's rhetorical stylization of his scientific ethos that contributed to his success.

$\mathrm{Du}$ Bois-Reymond dutifully acknowledged Hellenism as "the source of true education," adroitly attuning his self-fashioning to discursive philhellenic repertoires, in order to establish physiology as a high-ranking academic discipline (EBR 1886, 162). Veit-Brause has aptly summarized the challenge du Bois-Reymond's new discipline faced, observing that its "justificatory discourse had to be couched in the shared idiom of Bildung, that is, classical-literary learning" (Veit-Brause 2001, 38). ${ }^{5}$ We argue that du Bois-Reymond dealt with this challenge by rhetorically latching on to and adapting the philhellenic orientation of Berlin's university and the general public in his numerous academic and public speeches. ${ }^{6}$ This was facilitated by the fact that philhellenism was a highly flexible cultural repertoire and could easily be adapted to du Bois-Reymond's physiological expositions (Marchand 1996). ${ }^{7}$ In particular, we will show that the notions of supposedly Hellenic aesthetics, philosophy, and teaching that were peddled by nineteenth-century philhellenes proved malleable enough to be associated with physiological practices.

Dierig has analyzed a rendition of a portrait of Paul du Bois-Reymond, the physiologist's brother, as a young man with antique features (Dierig 2006). The portrait, showing a statuesque figure of a man whose muscular electric currents are being measured, was included in the second volume of Emil du Bois-Reymond's seminal Studies in Animal Electricity (1849). Dierig interprets the illustration as an allegorical self-portrait of Emil du Bois-Reymond exposing the Hellenic streak of his self-fashioning. However, Dierig's analysis neglects the larger philhellenic discourse of du Bois-Reymond's time and its stabilizing effect on traditional academic hierarchies. This article analyses du Bois-Reymond's struggles with the institutional and public hierarchies he faced as professor of physiology. We focus on issues of social membership, the "problem of 'recognition and being recognized"' (Gee 2011,34), analyzing du Bois-Reymond's rhetorical strategies of being considered a knowledgeable, erudite scholar and thus enhancing both his own authority and the prestige of his discipline (Potter 1996). Ruth Amossy has reconciled the apparent opposition between pragmatic concepts of authority, considering authority as deriving from rhetorical utterances, and sociological notions regarding it as a product of the speaker's institutional position and social status. She argues that speakers never construe their ethos, or authority, in a social vacuum, but always have to contend with the "prior ethos" (Amossy 2001, 7) inherent in the institutionalized roles, which individual speakers then tailor to their own persuasive purposes. Accordingly, our analysis of du Bois-Reymond's self-fashioning will consider the intricate relation between his institutional position and his rhetoric in achieving an authoritative standing. ${ }^{8}$

$\mathrm{Du}$ Bois-Reymond came to value the persuasive power of academic speeches in 1858 when his highly appreciated eulogy on the death of physiologist Johannes Müller launched his career. ${ }^{9} \mathrm{He}$

\footnotetext{
${ }^{5}$ Veit-Brause has already traced the nineteenth-century development of the schism between the natural sciences and the humanities at Berlin's university, arguing that physiologists eventually eroded the authority of historians (Veit-Brause 2001; see also Jardine 1997). However, Veit-Brause has not analyzed du Bois-Reymond's use of philhellenic repertoires in the process.

${ }^{6}$ For du Bois-Reymond, delivering academic and public speeches was an integral part of doing science. His speeches addressed very heterogeneous audiences and aimed at demarcating his discipline as well as increasing his academic and public status. We therefore hold that Emil du Bois-Reymond's making and communication of science are inextricably intertwined (Secord 2004).

${ }^{7}$ Rowe observes that the mid-nineteenth-century teaching and research practices of Prussian mathematicians, too, were informed by ancient literature and neo-humanist concepts (Rowe 1998, 12).

${ }^{8} \mathrm{We}$ consider rhetoric a crucial component of scientific practice in general and scientific self-fashioning in particular (Wesseling 2004). We understand "rhetoric" in the neutral sense of "the art of persuasion," rather than the negative sense of manipulative or deceitful use of language. Rhetoric is part and parcel of science, as scientists continuously communicate their findings to audiences within and beyond academia.

${ }^{9}$ Finkelstein (2013) claims that du Bois-Reymond's interest in rhetoric dates back to 1851 when he proof-read Humboldt's Cosmos, which he considered more compelling in style than in argument.
} 
frequently sought to renegotiate his prior ethos in his academic speeches and public addresses, increasing his authority as professor of physiology and preventing the risk of physiology becoming more closely associated with practical medicine than with the theoretical sciences. Our analysis draws on du Bois-Reymond's speeches, including the formal academic addresses he delivered, as well as his public winter lectures at Friedrich Wilhelm University and his popular itinerant lectures (Wandervorträge). The lectures and speeches addressed very diverse audiences, ranging from amateurs with an interest in science, at whom du Bois-Reymond's travelling lectures aimed, to medical students and fellow scientists. While most of du Bois-Reymond's formal addresses were already published in two extensive volumes during his lifetime (EBR 1886, 1887), our analysis of his university and itinerant lectures builds on the unpublished notes he took as a memory aid, as well as notes taken by his listeners. Public addresses, as opposed to letters or journal articles, are particularly relevant to our purpose because nineteenth-century philhellenism encouraged an obsession with the professorial voice, one that affirmed the putative objectivity of science by tying it to the charismatic authority of the professor (Clark 2003; Schroeder 2015). Moreover, the professorial voice endowed its scientific utterings with a "Socratic spirit" (Schroeder 2015, 46) that catered to the philhellenic educational institutions of du Bois-Reymond's time.

In order to substantiate our claim, we analyze in detail how Emil du Bois-Reymond mobilized philhellenic repertoires to construct the trustworthy scientific persona of the physiologist and ultimately boost the prestige of physiology (Daston and Sibum 2003; Wesseling 2004). We investigate how du Bois-Reymond not only adopted but also adapted philhellenic repertoires, building on previous investigations into rhetorical appropriations of discourse (Almási 2013; Bacon and McClish 2000; Campbell 1986; Lessl 2007; Shugart 1997). Repertoires not only feature in du Bois-Reymond's speeches as rhetorical topoi, or cultural commonplaces, but also as behavioral scripts, i.e. a set of widely shared assumptions regarding appropriate comportment in specific settings (Dhingra 2007). As such, repertoires provide an appropriate focal point for our twofold analysis of both rhetorical utterances and institutional practices in increasing du Bois-Reymond's public authority. We focus on three exemplary philhellenic repertoires that figure most prominently in du Bois-Reymond's speeches, namely the aestheticism of machines, Pyrrhonian skepticism, and the hierarchy of the senses. In conclusion, we explain how these repertoires supported $\mathrm{du}$ Bois-Reymond's claims to professorial esteem.

\section{The aestheticism of machines}

Striving to eradicate any traces of vitalism, du Bois-Reymond's physicalist physiology regarded the bodily functions of organisms as nothing more than a set of meticulous, perfectly interlocking physical and chemical mechanisms. This made it easier for him to distance physiology from practical medicine and place it within the orbit of the theoretical sciences of physics and chemistry. However, du Bois-Reymond's physicalist expositions ran the risk of being condemned as materialist and rather frightening descriptions of the human body as a soulless machine. Moreover, his demonstrations of vivisection, a practice that had caused public outrage in England, needed to be nested within a rhetoric that made the view of exposed muscles and organs more appealing to his audience.

We argue that du Bois-Reymond's tightrope act of conveying physiological experiments as physicalist yet attractive drew on philhellenic aestheticism to beautify his concept of bodily machines and make it more palatable to his audience. Du Bois-Reymond very explicitly praised the ancient Hellenic "sense for the eternally Beautiful, Good, and True" as the "highest measure" for what humanity might achieve in the cultural realm (EBR 1886, 311). Moreover, he condemned the common disregard for beauty and style in the research of fellow scientists. In 1890, in a speech delivered during a meeting of the Prussian Academy of Sciences, du Bois-Reymond criticized Gottfried Wilhelm Leibniz, cofounder of the academy: "He did not care much about beauty; 
in a word, never is this Hercules struck by an Omphale's dress" (EBR 1891a, 6). Ancient Queen Omphale, beautiful as she was, tried to seduce Leibniz in vain. Likewise, du Bois-Reymond disapproved of the lack of aesthetic form in the works of his mentor, physiologist Johannes Müller (Dierig 2006). In contrast to many of his colleagues, as Dierig $(2006,2010)$ has shown, du BoisReymond's experimental practices were shaped by a philhellenic aestheticism, with the physiologist propagating what he himself called an "aesthetics of the experiment" (EBR 1891a, 59).

Moreover, du Bois-Reymond's mechanization of the body functioned as a discursive script governing his everyday life. Being an avid gymnast, he constantly sought to perfect his technique, thus complying with the philhellenic ideal of a sound mind in a sound body (Young 2005). Dierig has already described these efforts at length, analyzing du Bois-Reymond's notion of "Bildung through bodily exercise in the handling of laboratory instruments." ${ }^{10}$ We argue that philhellenism not only shaped du Bois-Reymond's private lab activities but also his public self-fashioning. As the physiologist himself observed in 1883, conveying scientific insights to the "masses" was easier when the speaker shared the "common human sense for the Beautiful in the Sublime" (EBR 1886, 510).

Finkelstein has highlighted the influence of Epicurean materialism on du Bois-Reymond's thinking, observing that his physicalist physiology was probably formed by his reading of Lucretius' De Rerum Natura in the summer of 1838 (Finkelstein 2013, 248-253, 283). ${ }^{11}$ In his long didactic poem, Lucretius defends Epicurus' materialism, which regarded matter, living or not, as consisting exclusively of atoms in motion. The Epicurean atomistic concept, and more specifically Lucretius' appealing imagery of swirling atoms, provided the basis for du Bois-Reymond's compelling rhetoric centering on mechanical beauty. In his much-acclaimed 1872 speech On the Limits of Our Knowledge of Nature, du Bois-Reymond defined natural science as "the resolution of natural processes into the mechanics of atoms" (EBR 1874, 17). He then described these mechanics in more detail, wondering "what play of the carbon ... and other atoms, corresponds to the pleasure we experience on hearing musical sounds; what whirl of such atoms answers to the climax of sensual enjoyment" (ibid., 27). He went so far as to say that if all of Julius Caesar's atoms could be reproduced and put together mechanically, the artificial Caesar would be indistinguishable from the original. By building on Epicurean physics - and Lucretius' vivid depictions of wandering, clashing, leaping atoms - du Bois-Reymond's talk on bodies as atoms in motion not only corresponded with classical literary learning but offered his listeners imaginative landscapes of atoms at play.

Moreover, du Bois-Reymond's use of philhellenic rhetoric allowed him to thwart any negative associations which experimental physiology - and its growing dependence on vivisection in particular - might have evoked among his audience. Philhellenic aestheticism made it possible for du Bois-Reymond to frame the repugnant sight of dissected animals as a glimpse at beautiful bodily mechanics. In his public winter lectures at Friedrich Wilhelm University, du Bois-Reymond sought to counteract the traditional association of the human skeleton with death. His notes taken for his 1891-1892 winter lecture on physical anthropology state:

Thus the skeleton emerges, in the Middle Ages depicted as dreadful portrait of death, dance of death, Hans Holbein. In contrast to the ancients, Lessing. But this dread utterly pointless. Benvenuto Cellini. It has, like all animal skeletons, a mechanical beauty that relates to the plastic [beauty] like the elegance of a sonnet to that of a formula, deriving from utmost simplicity [and] expediency, like that of a machine. (EBR 1891/1892)

By referring to Gotthold Ephraim Lessing's interpretation of ancient depictions of skeletons Lessing had, in his polemical essay How the Ancients Represented Death allegedly proven that

\footnotetext{
10“Bildung durch Übung des Körpers im tätigen Umgang mit Laborinstrumenten” (Dierig 2006, 128).

${ }^{11}$ In his 1875 speech La Mettrie, du Bois-Reymond himself declared that his materialism followed up on the writings of Democritus, Epicurus, Lucretius, and La Mettrie (EBR 1886).
} 
ancient Greek depictions of skeletons did not symbolize death - du Bois-Reymond sought to dispel his listeners' dread of bones (Lessing 1769). The Renaissance sculptor and philhellene Benvenuto Cellini, whom the physiologist then referred to, even regarded knowledge of bones as a mnemonic aid of ancient origin. To the aspiring sculptor, bones were what rhetorical loci, organizational elements taught in Greek and Roman rhetorical treatises, were to the rhetor: a mnemonic scaffold reminding the sculptor of the right proportions of the human body (Cole 2001). Notably, du Bois-Reymond extended philhellenic aestheticism to include machines, speaking of a "mechanical beauty" of skeletons deriving from their efficiency. To him, the human body was not only a machine but, as he explained in his speech On Exercise in 1881, a "self-perfecting machine" ("Selbstvervollkommnungsmaschine" [EBR 1887, 406]). Du Bois-Reymond thus publicly adapted Humboldt's humanist ideal of Bildung through self-perfection by applying it to bodily, mechanical exercise (Dierig 2006). Moreover, according to the notes taken by one of his listeners, du BoisReymond stated in one of his winter lectures that, looking at the Hellenic statue of the Borghesian Gladiator, it was hard to believe the ancients did not dissect human bodies (Claude du BoisReymond, n.d.).

As Gooday has demonstrated, the nineteenth-century shift from scientists working outdoors to the indoor lab scientist, spurred by the invention and dissemination of the microscope, domesticated nature to legitimize the indoor study of outdoor phenomena (Gooday 1991). Giving physiological lectures required the subjugation of animal bodies to conducting reliable experiments: "highly artificial devices" were used to "visualize natural phenomena" (Schmidgen 2004, 507). $\mathrm{Du}$ Bois-Reymond justified physiological lab practice by emphasizing the beauty of mechanic organisms and, ultimately, the beauty of artifice, the attraction of man-made imitations of natural processes. Moreover, the physiologist retrospectively applied his concept of mechanical beauty to ancient architecture, claiming that the aesthetic appeal of simple Doric columns - as opposed to exuberant baroque architecture - already provided an early example of mechanic beauty (EBR 1891a). In short, du Bois-Reymond drew on philhellenic aestheticism to beautify his physiological expositions while at the same time redefining ancient aestheticism as efficient and mechanical.

Propagating the idea of mechanic beauty likely informed the fin-de-siècle aesthetic movement in the arts, which glorified artifice. As Joris-Karl Huysmans' (1884) protagonist and hopeless aesthete Des Esseintes puts it in Against the Grain: "Artifice ... seemed to Des Esseintes the final distinctive mark of man's genius. Nature has had her day, as he put it" (Huysmans [1884] 1922, 47). It was this discursive aesthetic predilection that allowed du Bois-Reymond to domesticate and elevate physiology, turning it into a study of ideals, of abstract formulae and of artifice. This view also pervaded his much-acclaimed 1872 speech The Limits of Our Knowledge of Nature, in which he continually favored artifice over nature: "Theoretically, a stretch of visual nerve could be ... replaced with a stretch of electric nerve without trouble" (EBR 1886, 109). Likewise, du BoisReymond spoke with reverence of the talking machines devised by inventors Wolfgang von Kempelen in the late eighteenth century and Joseph Faber in the mid-nineteenth century (EBRa n.d.). However, as du Bois-Reymond assured his audience in his 1875 speech La Mettrie, his mechanism was not inflated into an all-encompassing ideology or worldview. On the contrary, by limiting himself to observable mechanics and inductive methods, the scientist was to guard himself against all forms of scientism. By publicly stating the limitations of his scientific approach, the physiologist forestalled accusations of reaching beyond scientific boundaries.

$\mathrm{Du}$ Bois-Reymond further prevented such allegations by propagating an altered narrative of Prometheus' act of transgression, replacing the original myth with one that trivialized the stealing of fire. The term "modern Prometheus" had been used by Immanuel Kant in 1775, referring to Benjamin Franklin experimenting with electricity, and popularized by Mary Shelley's Frankenstein; or, The Modern Prometheus (1818). Like the Greek Titan Prometheus, Frankenstein makes a man out of non-living matter and is punished for his hubris. Shelley's novel has been read as testifying to the clash of romantic and materialist interpretations of electricity that pervaded experiments on electricity in the early nineteenth century (Morus 1998). Du Bois- 
Reymond, who himself specialized in electric currents in human and animal bodies, propagated a tale of Promethean science that emphasized the materialist side of the stealing of fire. He adapted the ancient myth of Prometheus in his itinerant lecture On the Circulation of Matter in Organic Nature, which he delivered in several cities. After explaining that plants depended on sunlight to produce carbon atoms, du Bois-Reymond concluded that it was the sun's energy that was set free in burning wood: "The flame in the fireplace is nothing but transmuted sunlight. We not only mimic 'with the hearth-flame the glow of a god' but like Prometheus we steal a real part of his embers" (EBR 1877-1879).

In addition to drawing on ancient mythology, du Bois-Reymond quoted from Friedrich Schiller's Punch Song (To Be Sung in the Northern Countries) (1803) that praises punch as an artificial, man-made surrogate for wine, gaining its glowing color from the hearth-flame instead of the sun. By referring to fire as transmuted sunlight, du Bois-Reymond refuted Schiller's description of the hearth-flame as merely mimicking sunlight, once again blurring the boundary between nature and artifice, and at the same time trivializing Prometheus' deceit. To du Bois-Reymond, nothing seemed more natural than stealing fire, in the sense of converting sunlight into carbon. He further explained that the same process could be observed in the human body burning calories, leading him to the conclusion that we "are all living torches," an image he would evoke more than once in his lectures (EBR 1877-1879).

Overall, du Bois-Reymond's use of the repertoire of aesthetic machines, or mechanic beauty, made it possible for him to portray experimental physiology as complying with the classicist aesthetic preferences of his contemporaries. At the same time, he adapted the Hellenic ideal of beauty, foregrounding its putative simplicity and expediency to make it seem like the origin of his own ideal of mechanic beauty. The philhellenic repertoire of aesthetic machines was complemented by one we term "confident skepticism," which served the purpose of framing experimental physiology as a modest, self-critical undertaking.

\section{Developing "confident skepticism"}

In his 1891/92 winter lectures on physical anthropology, du Bois-Reymond reinterpreted a popular classical doctrine and thereby consigned it to the realm of the natural sciences: "On the Temple of Apollo in Delphi it read: $\Gamma \nu \theta \imath \sigma \epsilon \alpha v \tau$ ó $\nu$ [know thyself]. Meaning of moral scolding ... The real meaning is, know the human, i.e .... anthropology" (EBR 1891/1892). Du Bois-Reymond's notes demonstrate how philhellenism was rhetorically integrated into the domain of the sciences, in this case anthropology. Zimmerman (2001) has documented the rise of scientific approaches to anthropology in late nineteenth-century Germany and observed that they gradually replaced humanist research methods. Du Bois-Reymond's notes on physical anthropology indicate that he, despite supporting scientific anthropology, stuck to humanist tenets. In the following, we will show that the physiologist not only redefined the classical saying "know thyself" but continued to foster its original skepticism - knowing one's limits - in his self-fashioning.

Du Bois-Reymond's provocative 1872 speech, The Limits of Our Knowledge of Nature, was an instant sensation among scientists that triggered the so-called Ignorabimus controversy. Du BoisReymond stated that science would never be able to explain either the nature of matter nor consciousness, ending his speech with ignoramus and ignorabimus - we do not and will not know. Throughout the 1870s, he further expanded his argument, before drawing it to a close in his speech The Seven Enigmas in 1880. It seems as if of all the reviews the latter speech provoked, du Bois-Reymond recovered only one favorable one, a review that complimented him on offering "a path to the quietude praised by Epicurus and Pyrrho" (Finkelstein 2013, 277).

Although du Bois-Reymond made strong claims for the explorative vigor of the natural sciences, he was nevertheless as preoccupied with articulating the limits of science as with promoting its possibilities. In his view, the natural scientist was not (and would never be) able to grasp the 
nature of matter or sentience. Any scientific attempt to overcome these boundaries would be no more successful than "an aeronaut essaying to reach the moon" (EBR 1874, 29). It seems safe to assume that du Bois-Reymond's contemporaries understood this remark as an allusion to Jules Verne's popular novel De la Terre à la Lune (1865), which describes the fictional endeavor of building an enormous canon and shooting three men into space. Du Bois-Reymond evidently relegated comprehending the nature of matter and human perception to the realm of pure science fiction. Was this indeed, as many of his listeners felt, a betrayal of the belief in scientific progress and thus a gratuitous act of self-debasement (Bayertz, Gerhard, and Jaeschke 2007)? We argue that the reactions to his 1872 speech illustrate a broader clash of nineteenth-century scientific views. According to Christopher Herbert (2001), the latter half of the century witnessed the rise of scientism, i.e. a dogmatic, moralizing belief in scientific objectivity (Toulmin 1990; Daston and Galison 1992). This scientific absolutism may be understood as a reaction to on-going doubts about the ideals of scientific certainty (Herbert 2001). With Toulmin (1990), modernity, in the sense of systematic skepticism, is actually binary: one tries to end doubt within the establishment of absolute certainty, the other embraces doubt as a way of life. Personified by the figureheads of René Descartes and Michel de Montaigne, these two modernities reflect the different aims of the sciences and the humanities.

Judging by the title of his speeches, du Bois-Reymond associated himself with doubt as a permanent attitude. Indeed, in the 1891 foreword to a publication of his speeches The Limits of Our Knowledge of Nature and The Seven Enigmas, he asserted that his observations inevitably led to "Pyrrhonism in a new garb" (EBR 1891b, 6). A philosopher belonging to the ancient school of Pyrrhonism "suspends judgment on all matters philosophical or speculative because he has found that no philosophical doctrines or beliefs can be conclusively justified” (Striker 2004, 13). Accordingly, the quote that precedes du Bois-Reymond's speech The Seven Enigmas reads, "Today, I have to confirm this confession with even stronger conviction, that, having read and meditated much more since that time, and having become more erudite, I feel even more that I do not know anything." 12 Although these lines were not explicitly attributed to any author in du Bois-Reymond's speech, they appear verbatim in Voltaire's Dictionnaire Philosophique (1764). Voltaire's skepticism was deeply indebted to Montaigne's skeptical views, regarding suspended judgement, a neo-Pyrrhonian attitude, as not just a momentary condition but a philosophical stance in its own right (Martin-Haag 1997; Shank 2015). Du Bois-Reymond refrained from the quest for absolute knowledge, a form of renunciation which seems to match the finde-siècle skepticism that has been described as the declaration of the "bankruptcy of science" (Paul 1968, 1). However, in his 1876 speech Darwin vs Galiani, du Bois-Reymond confidently asserted:

At the height of Pyrrhonism, yet free from giddiness, he [the natural scientist] refuses to fill the empty void around him with figments of his imagination and looks, unafraid, into the merciless mechanisms of de-deified nature.... Neither does he despairingly throw himself, like Empedocles, into the physical abyss whose secret he cannot fathom, nor, like Faust, into a moral abyss .... To him, like Lessing, not the possession of truth but the striving for truth is the higher good. (EBR 1886, 235)

As Herbert (2001) has observed, the opposite of nineteenth-century skepticism was not a concern for truth, but rather the belief that a group of people already possessed it. Skepticism led not to nihilism but rather to the acknowledgment of the limits of scientific knowledge and, ultimately, allowed for a more precise demarcation of the field of physiology. Du Bois-Reymond repeatedly rejected Cartesian dualism in favor of a Montaignian multifaceted skepticism (Toulmin 1990). Du

\footnotetext{
12“Je ratifie aujourd'hui cette confession avec d'autant plus d'empressement, qu'ayant depuis ce temps beaucoup plus lu, beaucoup plus médité, et étant plus instruit, je suis plus en état d'affirmer que je ne sais rien” (EBR 1886, 381).
} 
Bois-Reymond's most famous speech was influenced not only by Victorian writers like the physicist John Tyndall and the philosopher Henry Longueville Mansel, but also by an older line of French skeptics like Pascal, Bayle, La Mettrie, Voltaire and Diderot, "all of whom du BoisReymond read and cited” (Finkelstein 2013, 282f). However, du Bois-Reymond's frequent invocation of Pyrrhonism suggests that he built on an even older tradition consistent with the philhellenic education of his listeners.

Du Bois-Reymond linked his skepticism to an ascetic disavowal of absolute knowledge, cultivating the "wise self-effacement of the master" (EBR 1886, 389) as a form of scientific abstinence. In his 1877 speech on Cultural History and Natural Science, he painted a vivid picture of the modest natural scientist by quoting from Virgil's Aeneid: "She [natural science] has answered the yearning of the poet for Epicurus' disciple, whose mind is at ease: 'Blessed is he who has been able to understand the cause of things and has laid all kinds of fear and inexorable fate and the roar of the greedy Acheron under his feet"' (EBR 1886, 272). Du Bois-Reymond thus drew on the scientific persona of the ascetic truth-seeker, whose detachment from worldly affairs allows him to solve the riddles posed to science by natural phenomena (Daston and Sibum 2003; Shapin 1994; Veit-Brause 2002). Portraying the natural scientist as "Epicurus' disciple," with Epicureanism proclaiming that happiness could only be found in modesty, further integrated physiology into the philhellenic ideological framework of Berlin's university. Moreover, du Bois-Reymond's rhetorical self-fashioning as a skeptical, ascetic truth seeker was emphasized by his place of work. Dierig (2006) has described du Bois-Reymond's office at his physiological institute as a hermit's retreat, as an attempt at re-establishing the parlor laboratory of his early career. Also, in his lectures, du Bois-Reymond drew on the trope of the clairvoyant ascetic. The careful staging of his experiments evoked an almost saintly atmosphere (Dierig 2006; Finkelstein 2013), which supported du Bois-Reymond's self-fashioning as a high priest of natural science. Last but not least, in an intellectual environment shaped by biological determinism and a lingering fascination for phrenology, it was the scientist's impressive appearance which increased his holy aura, as journalist Adolph Kohut observed: "By this high forehead, which carries the mark of genius, we recognize the high priest of this temple of science: Emil du Bois-Reymond" (Kohut 1885). The physiologist himself was perceived as Epicurus' modest, confident disciple.

Du Bois-Reymond's skepticism liberated him from metaphysical speculation. Physiology could be confined to finding its own mechanical truths and let philosophers rack their brains about metaphysical problems concerning sensory perception. At the same time, skepticism also steered free from the dogma of vitalism, which reached for all-encompassing truths outside the purely mechanical realm of physiology. Thus, du Bois-Reymond's skepticism helped rid physiology of any vitalist relics and reduce it to its purely mechanical aspects, aligning it with the mechanical approach taken by the more highly acclaimed discipline of physics.

The development of his complex attitude of confident modesty culminated in du BoisReymond's exclamations of "ignoramus" and "ignorabimus" in his The Limits of Our Knowledge of Nature. A footnote he added to these words in an 1891 publication of the speech explains that, "Ignoramus' was the set phrase of the Old English grand jury where they felt indecisive about whether or not an indictment was rightful" (EBR 1891b, 66). This phrase, though modest, was certainly not without consequence, as it cleared the accused of all charges. In a similar vein, du Bois-Reymond's self-portrait as a wise man conscious of his limits aimed at a specific effect, namely to assert his scientific autonomy. "Between these limits," he said, referring to the nature of matter and human perception, "the man of science is lord and master; he dismembers and builds up, and no one durst say wherein his knowledge and his power are circumscribed" (EBR 1874, 29). Du Bois-Reymond's confident skepticism drew on ancient Pyrrhonian philosophy - "Pyrrhonism in a new garb" (EBR 1891b, 6) - to serve as the basis of his formulation of both scientific modesty and the power that science may yet exert within its proper limits. In a speech he delivered at a meeting of the Academy of Sciences in 1876, the physiologist made Laboremus the 
new shibboleth of science: the natural scientist could find solace, even delight, in his tireless striving for truth.

While Gunter Mann (1981) has argued that du Bois-Reymond tried to replace history with science, the physiologist in fact regarded the disciplines as complementary (Finkelstein 2013). History and science come together in du Bois-Reymond's skepticism, since he relied on history to guard himself and his students against dogmatism. In his 1872 speech On History of Science, delivered at a meeting of the Academy of Sciences, du Bois-Reymond stated that "the best way of communicating science may be narrating its history" (EBR 1887, 350). He linked science to ancient mythology by referring to natural scientists as "demigods" (ibid.). However, this selfconfident exclamation did not attest to any desire to replace ancient history with science. This became evident as du Bois-Reymond further elaborated on his concept in On History of Science: "This [historical] method can well be of great advantage in the scientific domains that rely on induction, for example physiology. I take the inductive account to be the right way of presenting physiology, both in the lecture hall and in the textbook, in contrast to the dogmatic account frequently used in textbooks" (EBR 1887, 351).

Evidently, history as a means of furthering his students' skepticism strongly influenced du Bois-Reymond's teaching. He utilized the history of science as university teacher to both instill skepticism in his students and to exalt the "demigods" of natural science. By presenting how a researcher arrived at a set of conclusions, their findings were rendered reproducible and, thus, disputable. As Jardine (1997) has already shown, du Bois-Reymond's version of the history of science, presenting it as an incessant process of verifying or refuting previous scientific results through experiment, served as a vehicle for promoting experimental practices in physiology. Also, du Bois-Reymond claimed that delivering inductive accounts of scientific experiments made his lectures more entertaining: "When presenting it this way, science excites interest that, when compared with the interest aroused by dogmatism, is like the interest evoked by an epic compared with that of a didactic poem" (EBR 1887, 352). This way of teaching allowed du Bois-Reymond and his discipline to win recognition, as the Berliner Fremdenblatt reported: "He [du BoisReymond] has become one of the greatest methodologists of our times, all the more significant due to his wide knowledge of the history of science" (Anon. 1882). Notably, du Bois-Reymond was convinced that his philhellenic skepticism also guarded him and his students against what he perceived as utilitarian "Americanism" - an overly instrumental notion of science as fulfilling citizens' day-to-day needs without pondering any more profound questions. He regarded the contemplation of ancient Greek ideals as an antidote to this excessively utilitarian form of science, declaring in his 1877 speech on Cultural History and Natural Science: "May Hellenism keep Americanism out of our minds" (EBR 1886, 283).

To sum up, conjoining Pyrrhonian skepticism with experimental physiology enabled du Bois-Reymond to appear as a modest disciple of Epicurus, thus winning the esteem of humanist academia and society. His skepticism was empowering, as it demarcated the future tasks and methods of the burgeoning life sciences. The physiologist's version of the history of science as a didactical tool, a skeptical approach to previous research results, promoted his own experimental methods. At the same time, as we will show in the following, du Bois-Reymond elevated the observation of bodily functions through experiment as a valid research method by contributing to a remodeling of the university's established hierarchy of the senses.

\section{Challenging the hierarchy of the senses}

Nineteenth-century Graecophilia coincided with an academic concentration on language, which favored the ear above the eye (Marchand 1996). This hierarchy of the senses was inextricably intertwined with a hierarchy of academic disciplines, favoring those relying on listening as their main analytical device over those relying on eyesight (McCance 2004). Physiology, depending on 
vivisection and what came to be known as Anschauungsunterricht (Schmidgen 2004), the teaching by visual perception, could therefore not easily ascend to the higher ranks of Berlin's academic hierarchy. Although, as Kremer (1992) has shown, physiologists had promoted the institutionalization of Anschauungsunterricht at universities at least since the 1830s, Prussian school teaching especially at the humanist Gymnasium - continued to revolve around the humanities. In his 1877 speech on Cultural History and Natural Science, du Bois-Reymond argued for a better integration of the natural sciences into school curricula, yet it was not until the Prussian school reforms of the 1890s that school teaching finally saw "the emancipation ... of the eye from the ear, of the 'living' image from the dying word” (Marchand 1996, 145).

How, then, did du Bois-Reymond's addresses cater to audiences whose humanist education was based on oral instead of visual instruction? We suggest that part of the answer to this question lies in the scientist's long interest in synesthesia. In 1840, du Bois-Reymond drafted a report on his personal experiences of auditory-visual synesthesia, his Note on Imagining Aural Perceptions in Space, which described the three-dimensional objects he perceived on hearing certain sounds. Although Johannes Müller criticized du Bois-Reymond's essay for being too subjective and advised against publishing it (Finkelstein 2013, 53), his notion of the senses as being interwoven continued to shape the physiologist's speeches and lectures. In his On the Limits of Our Knowledge of Nature, du Bois-Reymond described a peculiar, synesthetic experiment:

As in the experiment suggested by Bidder and successfully made by Vulpian on the nerves of taste, ... fibres from different sets of nerves would blend perfectly together. With the nerves of vision and of hearing severed, and then crossed with each other, we should with the eye hear the lightning-flash as a thunder-clap, and with the ear we should see the thunder as a series of luminous impressions. (EBR 1874, 19)

This passage demonstrates du Bois-Reymond's scientific appropriation of the rhetorical trope of synesthesia. A trope characteristic of Romantic poetry, testifying to the longing for perceptual universalism, now illustrates the outcome of a strictly scientific experiment. Thus, du BoisReymond levelled the hierarchy of the senses by pointing out their physiological interrelatedness. While this may have been the most obvious instance of synesthesia in his speeches, du BoisReymond used the trope more often in subtle ways, speaking, for example, of the "bright, glowing, resonant world around us" (EBR 1874, 20). At the same time, he also took recourse to contemporary theories of music. Notes taken by his students confirm that du Bois-Reymond lectured on mathematical and physiological acoustics as part of his lecture series on Special Physiology (Körting n.d.). Moreover, Hermann von Helmholtz, du Bois-Reymond's colleague and friend, frequently experimented with sound and coined the term Klangfarbe, "tone color" or timbre (Helmholtz 1859). Color and vision thus came to be associated with music. The idea was not completely new at the time: the previous century had witnessed the invention of LouisBertrand Castel's ocular harpsichord. The instrument sought to combine colors with sound, "popularized the equation of pitch with colour" and "helped to alter the discourse around music" (Dolan 2013, 15). The synesthetic dimension of music theory was grist to du Bois-Reymond's mill. His own collection of notes for his lectures on Special Physiology includes a diagram of Klangfarben, a "comparison of musical tones with colours according to Helmholtz" (EBRb n.d.).

At the same time, du Bois-Reymond sought to turn the study of sound and language into a physiological domain. Although traditionally studied by the university's philologists, understanding the production of language, as du Bois-Reymond saw it, actually required a physiological approach. This approach, already championed by Johannes Müller, was also propagated by du Bois-Reymond's friends Ernst Brücke and Hermann von Helmholtz, who were equally interested in the physiology of sound and speech (Brain 2015, 75). In his itinerant lecture On the Voice and Language, du Bois-Reymond focused on the production of sound in the larynx. His physiological approach allowed him to draw some startling conclusions that were at odds with philological 
learning. He asserted that, from a physiological perspective, Umlaute were practically indistinguishable from vocals and should be included in the German alphabet. Likewise, he claimed, the distinction between head voice and chest voice made no sense at all, considering that the human voice was always produced by vibrations of the vocal cords. Finally, he assigned the human capacity of language production to a particular part of the brain: "if it is language that makes us human, we can say that it is this small part of the brain that makes us so" (EBRa n.d.). Thus, the production of language was reinterpreted as a cranial process requiring elucidation by physiology. Likewise, in his university lectures, du Bois-Reymond described the functioning of the aural sense in purely physiological terms (Körting n.d.). Brain (2015) has already convincingly shown that physiological experiments on language had a lasting effect on late nineteenth-century art. We suggest that, vice versa, the appropriation of language through physiology helped to undermine philological authority over the interpretation of language.

In his On the Voice and Language du Bois-Reymond recalled a device invented by a London singing teacher to observe the larynx of a living human being. Du Bois-Reymond himself relied on an array of devices to make physiological phenomena visible to his students. In 1877, he stated that the physiological lecture hall must be turned into a "stage for natural phenomena" (EBR 1887, 367). English lectures had already been transformed into performances by physicist Michael Faraday, who intended to "make science a polite entertainment requiring the sort of suspension of disbelief that is associated with the theatre" (James 2002, 227). Du Bois-Reymond followed suit. He prided himself on introducing English posters to Berlin's university, "a powerful teaching aid" (EBR 1887, 363), although he was, in fact, not the first to use visual aids at the institution (Güttler 2015).

$\mathrm{Du}$ Bois-Reymond's entire lecture hall was designed to let large audiences witness the tiniest movement of a twitching frog's leg (Dierig 2006; Schmidgen 2004). Moreover, auditory teaching devices could be used as supplements when relying on eyesight alone was hardly possible, as Westermann's illustrierte Deutsche Monatshefte reported:

When the object is too tiny to be seen by all spectators, enlarged drawings are used in some cases, while an ingenious solution has been found in others. When the experiment aims at, for example, demonstrating the influence of the pneumogastric nerve on the heartbeat of a frog or rabbit, it is conducted in such a way that the heart strikes a bell with every beat and shows its movements to the audience through a clear sound. (Kohut 1885)

Du Bois-Reymond's physiological lectures thus combined the scientist's voice with a range of visual effects, enhancing the synesthetic effect of his speeches through the use of illustrations, sometimes combining them with auditory teaching aids. In keeping with the high esteem in which the aural sense was held, students attending the lectures of du Bois-Reymond were often impressed by his "sonorous" delivery and "remarked the lucidity of his expression, the splendour of his imagery, and the breadth of his erudition" (Finkelstein 2013, 176). The scientist could therefore capitalize upon the nineteenth-century fascination with the professorial voice (Schroeder 2015).

Du Bois-Reymond also became known for his public interventions in Prussian school education and was seen as an advocate for the rhetorical training of scientists and medical students. His 1874 speech On an Imperial Academy for the German Language, given at a meeting of the Academy of Sciences, advocated for the establishment of a national academy modelled on the Académie française. The physiologist mocked the neglect of style among his fellow scientists and implored them to treat their scientific papers as works of literature instead. He was convinced that instituting an academy for the German language would improve the standard of scientific writing. Evidently, du Bois-Reymond acknowledged the superior style of humanist writing and encouraged his colleagues to do the same. He sensed that experimental results would be more 
compelling when the insights of close observation were presented in a rhetoric that tallied with traditional humanist teaching.

In his itinerant lecture On the Sense of Touch (1884), du Bois-Reymond sought to convince his audience of the importance of the tactile sense. Although touch was usually considered the "lowest" of the senses, du Bois-Reymond claimed it deserved more appreciation. He held that it was only our sense of touch that could perceive a broad range of very different sensations, like temperature, pain, hunger, lust or muscular contraction (EBR 1884). Whereas the rhetorical advancement of vision served to legitimize observational practices of experiment, elevating the sense of touch rather aimed at justifying du Bois-Reymond's own interest in the electrical properties of nerve and muscle. For many years he had been preoccupied with understanding the role electricity played in the stimulation of nerves and the contraction of muscles. Emphasizing the complexity of tactile sensation was ultimately aimed at raising the status of du Bois-Reymond's research in the eyes of the public.

The opening of a new institute of physiology in 1877 finally enabled du Bois-Reymond to challenge the philhellenic hierarchy of the senses more openly. The "magnificent building" significantly augmented du Bois-Reymond's prestige as its director ("Prachtbau" [EBR 1887, 378]). Addressing the future students of the institute in 1877, he went so far as to suggest that sight would triumph over sound:

Listening carefully to oral lectures and writing them down as truthfully as possible, as laudable as that may be, means, in your case, that you have accomplished only one part of the task. Even if, due to your one-sided humanist education, it may cost you quite an effort, you have to see for yourselves and convince yourselves. You must not believe here but experiment and dare to know; and you must not, as often happens, avoid the opportunity to see only because you think seeing is too difficult for you. (EBR 1887, 381)

Stating that students of physiology must "dare to know" obviously alluded to the Kantian imperative of sapere aude. The scientific gaze was the key to independent, unmitigated research, and the warrant of du Bois-Reymond's ethos of an Enlightenment reformer. However, even at this stage he did not suggest putting an end to the philhellenic orientation of his university. Instead, he pointed out how Greek philology might benefit from physiological methods, saying that "by presenting pictures to the students, one might teach them more true Hellenism in just a few hours than by lengthy speeches" (EBR 1886, 294). Philhellenism, understood as the self-critical, tireless striving for truth, and informed by Epicurean and Pyrrhonian thinking, could be taught through the observations of physiology just as well as through the teachings of philology.

\section{Conclusion}

The previous sections have shown how Emil du Bois-Reymond attuned the philhellenic repertoires of his time to his own rhetorical purposes. In fashioning himself as professor of physiology, he did, indeed, draw on institutionalized philhellenism to establish physiology as a prestigious academic discipline. Du Bois-Reymond's rhetorical strategy mediated between the sciences and humanities on various levels. He employed philhellenic aestheticism to conceptualize natural organisms as artificial mechanisms and forestalled allegations of scientific hubris by adopting a Pyrrhonian, skeptical attitude. Furthermore, he drew on personal experiences of synesthesia to challenge the philhellenic hierarchy of the senses. Du Bois-Reymond's Pyrrhonian skepticism helped free physiology from purely metaphysical concerns, attesting to the "hidden agenda" (Toulmin 1990) of nineteenth-century relativism and its appreciation of the history of science. Adopting a relativist discourse that had been shaped by the humanities rather than the sciences, du Bois-Reymond was able to fashion himself as an interdisciplinary researcher situated at the 
median between the sciences and humanities. The philhellenic repertoires mobilized by du BoisReymond also helped to publicly legitimize his methods of research and teaching, including his treatment of the body as a machine.

Since he aimed at gaining prestige not only within academia but also within wider circles of the German intelligentsia, du Bois-Reymond's self-fashioning went hand in hand with the popularization of the experimental life sciences. As numerous newspaper reports assert, he came to be seen as a "popular writer" (Zacharias 1883), always "gaining attention whenever he appeared before the public" (Kastan 1883). Du Bois-Reymond was described as "a professor of mankind, having for pupils educated men all over the world, teaching them the fundamental elements of all our wisdom, teaching them to read the sybil leaves of Nature" (Griez 1884). Obviously, du BoisReymond's grafting of his own scientific purposes on the commonplaces of the humanities helped to popularize his experimental methods. In short, du Bois-Reymond's use of philhellenic rhetoric not only facilitated the institutionalization of experimental physiology as an academic discipline but also familiarized the public with his experimental practices.

Even after the opening of the splendid physiological institute, du Bois-Reymond did not call for an end to philhellenism. Instead, he presented physiology as a renovator of humanist learning, as a means to access the truth buried under decades of dry philological education: "Being steeped in Greek ideals and ideas can also be achieved without the excruciating trouble of learning how to put together a few Greek sentences, which is often of little use in life" (EBR 1886, 293). Du BoisReymond always preferred modest reform to blatant revolution (Finkelstein 2013). Yet his subtle adaptations of philhellenic repertoires proved to be powerful rhetorical tools. The physiologist both couched physiology in philhellenic learning and at the same time adjusted philhellenic repertoires to accommodate his scientific outlook and experimental methods. Du Bois-Reymond's pact with the humanities was twofold. On the one hand, he sought to rid physiology of metaphysical concerns, widening the gap between the humanities and sciences. On the other hand, his support of skepticism facilitated a fruitful exchange between the humanities and sciences that used history to guard himself against scientific dogmatism.

The successful institutionalization of du Bois-Reymond's discipline owed much to the scientific achievements of the physiologist, his fellow researchers at Berlin's university, and to the experimental and institutional groundwork laid by Johannes Müller. Du Bois-Reymond's rhetorical strategies complemented these efforts and helped to define the relation between experimental physiology and the humanities and to cement the position of physiology as a research-oriented discipline within the philosophical faculty. The case of du Bois-Reymond illustrates how much the life sciences once had to assert their value in opposition to medicine and the humanities. Even today, despite the firmly established dominance of the life sciences, the negotiation of scientific hierarchies remains a salient issue in "the academic caste system" (Burris 2004; see also Smith, Best, Stubbs, Johnston and Archibald 2000; Peterson 2015). Therefore, investigating the rhetorical self-fashioning of Emil du Bois-Reymond helps to deepen our insight into the contestations and contingencies of disciplinary hierarchies, and into processes of discipline formation in the nineteenth-century history and sociology of science.

Acknowledgments. We would like to thank Gabriel Finkelstein for his generous advice during the writing process. We also thank our anonymous reviewers and the editors for their thoughtful comments.

\section{References}

Almási, Gábor. 2013. "Tycho Brahe and the Separation of Astronomy from Astrology: The Making of a New Scientific Discourse." Science in Context 26(1):3-30.

Amossy, Ruth. 2001. "Ethos at the Crossroads of Disciplines: Rhetoric, Pragmatics, Sociology." Poetics Today 22(1):1-24.

Anon. 1882. "Emil du Bois-Reymond: Zum Rektoratswechsel der Berliner Universität am 15. Oktober." Berliner Fremdenblatt. Newspaper clipping. Box 2, Folder 1, Nachlass Emil du Bois-Reymond, Handschriftenabteilung, Staatsbibliothek zu Berlin - Preußischer Kulturbesitz. 
Bacon, Jacqueline, and Glen McClish. 2000. "Reinventing the Master's Tools: Nineteenth-Century African-American Literary Societies of Philadelphia and Rhetorical Education.” Rhetoric Society Quarterly 30(4):19-47.

Bayertz, Kurt, Myriam Gerhard, and Walter Jaeschke, eds. 2007. Weltanschauung, Philosophie und Naturwissenschaft im 19. Jahrhundert. 3 vols. Hamburg: Felix Meiner.

Brain, Robert Michael. 2015. The Pulse of Modernism: Physiological Aesthetics in Fin-de-Siècle Europe. Seattle and London: The University of Washington Press.

Burris, Val. 2004. "The Academic Caste System: Prestige Hierarchies in PhD Exchange Networks." American Sociological Review 69(2):239-264.

Campbell, John Angus. 1986. “Scientific Revolution and the Grammar of Culture: The Case of Darwin's Origin.” Quarterly Journal of Speech 72(4):351-376.

Clark, William. 2003. "On the Professorial Voice." Science in Context 16(1-2):43-57.

Cole, Michael. 2001. "The Figura Sforzata: Modelling, Power and the Mannerist Body.” Art History 24(4):520-551.

Daston, Lorraine, and Peter Galison. 1992. "The Image of Objectivity." Representations 40:81-128.

Daston, Lorraine, and Otto Sibum. 2003. "Introduction: Scientific Personae and Their Histories." Science in Context 16(1/2): $1-8$.

Dhingra, Pawan. 2007. Managing Multicultural Lives: Asian American Professionals and the Challenge of Multiple Identities. Stanford: Stanford University Press.

Dierig, Sven. 2006. Wissenschaft in der Maschinenstadt: Emil Du Bois-Reymond und seine Laboratorien in Berlin. Göttingen: Wallstein Verlag.

Dierig, Sven. 2010. “Apollo's Tragedy: Laboratory Science between Classicism and Industrial Modernism.” In Science as Cultural Practice, vol. 1, edited by Moritz Epple and Claus Zittel. Berlin: De Gruyter.

Dolan, Emily I. 2013. The Orchestral Revolution: Haydn and the Technologies of Timbre. Cambridge: Cambridge University Press.

du Bois-Reymond, Claude. N.d. “Übertragung in Langschrift einer nicht gezählten Vorlesung von Claude Du Bois-Reymond (?).” Box 2, Folder 2, Nachlass Emil du Bois-Reymond, Handschriftenabteilung, Staatsbibliothek zu Berlin - Preußischer Kulturbesitz.

du Bois-Reymond, Emil. 1849. Untersuchungen über thierische Electricität. Zweiter Band. Berlin: G. Reimer.

du Bois-Reymond, Emil. 1874. "The Limits of Our Knowledge of Nature.” Translated by J. Fitzgerald. Popular Science Monthly 5:17-32.

du Bois-Reymond, Emil. 1877-1879. "Kreislauf des Stoffes in der Organischen Natur.” Box 8, Folder 2, Nachlass Emil du Bois-Reymond, Handschriftenabteilung, Staatsbibliothek zu Berlin - Preußischer Kulturbesitz.

du Bois-Reymond, Emil. 1884. "Über den Gefühlssinn." Box 8, Folder 2, Nachlass Emil du Bois-Reymond, Handschriftenabteilung, Staatsbibliothek zu Berlin - Preußischer Kulturbesitz.

du Bois-Reymond, Emil. 1886. Reden von Emil du Bois-Reymond. Erste Folge. Leipzig: Veit.

du Bois-Reymond, Emil. 1887. Reden von Emil du Bois-Reymond. Zweite Folge. Leipzig: Veit.

du Bois-Reymond, Emil. 1891a. Naturwissenschaft und Bildende Kunst. Rede zur Feier des Leibnizischen Jahrestages in der Akademie der Wissenschaften zu Berlin am 3. Juli 1890 gehalten von Emil du Bois-Reymond. Leipzig: Veit.

du Bois-Reymond, Emil. 1891b. Über die Grenzen des Naturerkennens: Die sieben Welträthsel. Zwei Vorträge von Emil du Bois-Reymond. Leipzig: Veit.

du Bois-Reymond, Emil. 1891/1892. "Physische Anthropologie." Box 16, Folder 16, Nachlass Emil du Bois-Reymond, Handschriftenabteilung, Staatsbibliothek zu Berlin - Preußischer Kulturbesitz.

du Bois-Reymond, Emil. N.d.-a. "Stimme und Sprache." Box 8, Folder 2, Nachlass Emil du Bois-Reymond, Handschriftenabteilung, Staatsbibliothek zu Berlin - Preußischer Kulturbesitz.

du Bois-Reymond, Emil. N.d.-b. "Specielle Physiologie." Box 15, Black folder, Nachlass Emil du Bois-Reymond, Handschriftenabteilung, Staatsbibliothek zu Berlin - Preußischer Kulturbesitz.

Finkelstein, Gabriel. 2013. Emil du Bois-Reymond: Neuroscience, Self, and Society in Nineteenth-Century Germany. Cambridge MA: The MIT Press.

Gee, James Paul. 2011. An Introduction to Discourse Analysis: Theory and Method. New York: Routledge.

Gooday, Graeme. 1991. "Nature' in the Laboratory: Domestication and Discipline with the Microscope in Victorian Life Science." The British Journal for the History of Science 24(3):307-341.

Griez. 1884. "Untitled Nobility of Germany and Austria. XVI: Emil Du Bois-Reymond." The Current: Literature, Current Thought and Events. Newspaper clipping. Box 2, Folder 1, Nachlass Emil du Bois-Reymond, Handschriftenabteilung, Staatsbibliothek zu Berlin - Preußischer Kulturbesitz.

Güttler, Nils. 2015. "Drawing the Line: Mapping Cultivated Plants and Seeing Nature in Nineteenth-Century Plant Geography." In New Perspectives on the History of Life Sciences and Agriculture, edited by Denise Phillips and Sharon Kingsland, 27-52. Basel: Springer International Publishing.

Helmholtz, Hermann von. 1859. "Ueber die Klangfarbe der Vocale." Annalen der Physik 184(10):280-290.

Herbert, Christopher. 2001. Victorian Relativity: Radical Thought and Scientific Discovery. Chicago: University of Chicago Press. 
Huysmans, Joris-Karl. [1884] 1922. Against the Grain. Translated by John Howard. New York: Lieber \& Lewis.

James, Frank A. J. L. 2002. "Never Talk about Science, Show it to Them': The Lecture Theatre of the Royal Institution." Interdisciplinary Science Reviews 27(3):225-229.

Jardine, Nicholas. 1997. "The Mantle of Müller and the Ghost of Goethe: Interactions between the Sciences and Their Histories." In History and the Disciplines. The Reclassification of Knowledge in Early Modern Europe, edited by Donald R. Kelley, 297-318. Rochester: The University of Rochester Press.

Kastan, Isidor. 1883. "Emil Dubois-Reymond." Berliner Tageblatt. Erstes Beiblatt. Newspaper clipping. Box 2, Folder 1, Nachlass Emil du Bois-Reymond, Handschriftenabteilung, Staatsbibliothek zu Berlin - Preußischer Kulturbesitz.

Körting, George. N.d. "Physiologie. Vorlesungsnachschrift, SS 1864 und WS 1864/65.” Box 11, Folder 22, Nachlass Emil du Bois-Reymond, Handschriftenabteilung, Staatsbibliothek zu Berlin - Preußischer Kulturbesitz.

Kohut, Adolph. 1885. "Emil du Bois-Reymond." Westermann's illustrierte Deutsche Monatshefte für das gesamte geistige Leben der Gegenwart. Newspaper clipping. Box 2, Folder 1, Nachlass Emil du Bois-Reymond, Handschriftenabteilung, Staatsbibliothek zu Berlin - Preußischer Kulturbesitz.

Kremer, Richard L. 1992. "Building Institutes for Physiology in Prussia, 1836-1846: Contexts, Interests, Rhetoric.” In The Laboratory Revolution in Medicine, edited by Andrew Cunningham and William Perry, 72-109. Cambridge: Cambridge University Press.

Lehmann, Joseph. 1873. "Du Bois-Reymond: Ueber die Gränzen des Natur-Erkennens. I: Vom philosophischen Standpunkte eines Theologen.” Magazin für die Literatur des Auslandes. Newspaper clipping. Box 4, Folder 1, Nachlass Emil du BoisReymond, Handschriftenabteilung, Staatsbibliothek zu Berlin - Preußischer Kulturbesitz.

Lessing, Gotthold E. 1769. Wie die Alten den Tod gebildet: eine Untersuchung von Gotthold Ephraim Lessing. Berlin: Christian Friedrich Voß.

Lessl, Thomas M. 2007. "The Culture of Science and the Rhetoric of Scientism: From Francis Bacon to the Darwin Fish." Quarterly Journal of Speech 93(2):123-149.

Mann, Gunter. 1981. "Geschichte als Wissenschaft und Wissenschaftsgeschichte bei Du Bois-Reymond.” In Naturwissen und Erkenntnis im 19. Jahrhundert: Emil Du Bois-Reymond, edited by Gunter Mann, 149-172. Hildesheim: Gerstenberg Verlag.

Marchand, Suzanne L. 1996. Down from Olympus: Archaeology and Philhellenism in Germany, 1750-1970. Princeton: Princeton University Press.

Martin-Haag, Éliane. 1997. "Diderot et Voltaire lecteurs de Montaigne: du jugement suspendu à la raison libre." Revue de Métaphysique et de Morale 3:365-383.

McCance, Dawne. 2004. Medusa's Ear: University Foundings from Kant to Chora L. Albany: State University of New York Press.

Morus, Iwan. 1998. Frankenstein's Children: Electricity, Exhibition, and Experiment in Early-Nineteenth-Century London. Princeton: Princeton University Press.

Otis, Laura. 2007. Müller's Lab. Oxford: Oxford University Press.

Parnes, Ohad. 2003. "From Agents to Cells: Theodor Schwann's Research Notes of the Years 1835-1838." In Reworking the Bench: Research Notebooks in the History of Science, edited by Frederic L. Holmes, Jürgen Renn and Hans-Jörg Rheinberger, 119-140. New York: Kluwer Academic Publishers.

Paul, Harry W. 1968. "The Debate over the Bankruptcy of Science in 1895." French Historical Studies 5(3):299-327.

Peterson, David. 2015. "All That Is Solid: Bench-Building at the Frontiers of Two Experimental Sciences." American Sociological Review 80(6):1201-1225.

Potter, Jonathan. 1996. Representing Reality: Discourse, Rhetoric and Social Construction. London: Sage.

Rowe, David E. 1998. "Mathematics in Berlin, 1810-1933." In Mathematics in Berlin, edited by Heinrich Begehr, Helmut Koch, Jürg Kramer, Norbert Schappacher and Ernst-Jochen Thiele, 9-26. Basel: Springer.

Schmidgen, Henning. 2004. "Pictures, Preparations, and Living Processes: The Production of Immediate Visual Perception (Anschauung) in late-19-Century-Physiology." Journal of the History of Biology 37(3):477-513.

Schroeder, Janice. 2015. “The Schooled Voice: Sound and Sense in the Victorian Schoolroom." Zeitschrift für Anglistik und Amerikanistik 63(1):31-49.

Secord, James. 2004. “Knowledge in Transit." Isis 95(4):654-672.

Shank, J. B. 2015. "Voltaire." The Stanford Encyclopedia of Philosophy. Fall 2015 Edition, edited by Edward N. Zalta. Stanford University. 21 August 2016 http://plato.stanford.edu/archives/fall2015/entries/voltaire/.

Shapin, Steven. 1994. A Social History of Truth: Civility and Science in Seventeenth-Century England. Chicago: University of Chicago Press.

Shugart, Helene A. 1997. "Counterhegemonic Acts: Appropriation as a Feminist Rhetorical Strategy." Quarterly Journal of Speech 83(2):210-229.

Smith, Laurence D., Lisa A. Best, D. Alan Stubbs, John Johnston, and Andrea Bastiani Archibald. 2000. "Scientific Graphs and the Hierarchy of the Sciences: A Latourian Survey of Inscription Practices.” Social Studies of Science 30(1):73-94.

Striker, Gisela. 2004. "Historical Reflections on Classical Pyrrhonism and neo-Pyrrhonism." In Pyrrhonian Skepticism, edited by Walter Sinnott-Armstrong, 13-24. Oxford: Oxford University Press.

Tenorth, Heinz-Elmar, ed. 2012-2015. Geschichte der Universität Unter den Linden 1810-2010. 6 vols. Berlin: de Gruyter. 
Toulmin, Stephen. 1990. Cosmopolis: The Hidden Agenda of Modernity. Chicago: University of Chicago Press.

Veit-Brause, Irmline. 2001. "Scientists and the Cultural Politics of Academic Disciplines in Late 19th-century Germany: Emil Du Bois-Reymond and the Controversy over the Role of the Cultural Sciences." History of the Human Sciences 14(4):31-56.

Veit-Brause, Irmline. 2002. "The Making of Modern Scientific Personae: The Scientist as a Moral Person? Emil Du BoisReymond and His Friends." History of the Human Sciences 15(4):19-49.

Wesseling, Elisabeth. 2004. "Judith Rich Harris: The Miss Marple of Developmental Psychology." Science in Context 17(3):293-314.

Williamson, George S. 2004. The Longing for Myth in Germany: Religion and Aesthetic Culture from Romanticism to Nietzsche. Chicago and London: The University of Chicago Press.

Young, David C. 2005. "Mens Sana in Corpore Sano? Body and Mind in Ancient Greece." The International Journal of the History of Sport 22(1):22-41.

Zacharias, Otto. 1883. "Prof. Emil du Bois-Reymond.” Niederschlesischer Anzeiger. Newspaper clipping. Box 2, Folder 1, Nachlass Emil du Bois-Reymond, Handschriftenabteilung, Staatsbibliothek zu Berlin - Preußischer Kulturbesitz.

Zimmerman, Andrew. 2001. Anthropology and Antihumanism in Imperial Germany. Chicago and London: The University of Chicago Press.

Lea Beiermann is a $\mathrm{PhD}$ candidate at the History Department of the Faculty of Arts and Social Sciences, Maastricht University. She is a member of the MUSTS research group (Maastricht University Science, Technology \& Society Studies). Her PhD research looks at the formation of an international microscopy community in the mid- and late nineteenth century.

Elisabeth (Lies) Wesseling is professor of Cultural Memory, Gender and Diversity at the Faculty of Arts and Social Sciences of Maastricht University., where she directs the Centre for Gender and Diversity (www.maastrichtuniversity.nl/CGD). She publishes on self-fashioning in science, psychology in (popular) culture and on 'selling colonialism' to Dutch children in the Netherlands between 1890 and 1940, using textbooks and children's literature as main sources.

Cite this article: Beiermann, Lea and Elisabeth Wesseling. 2020. "Physiology and Philhellenism in the Late Nineteenth Century: The Self-Fashioning of Emil du Bois-Reymond," Science in Context 33:19-35. doi:10.1017/S0269889720000101 